Shortage of space for display and storage has prompted the Council to rebuild on the present site. Some of the very old buildings are structurally unsound, and would be most uneconomical to maintain in good repair. They will be demolished and replaced by a new building which will incorporate any suitable existing buildings. The scheme for rebuilding includes a new Locomotive Hall, an administrative block and an Engineering Hall. The scheme will be carried out in three phases over a period of several years. The total cost including professional fees will be in the region of $£ 655,000$.

\section{Meteorites in the U.S.S.R.}

IN the first quarter of the last century, certain curiously shaped hollows were discovered on the land surface of the Island of Sarema in Estonia, but it was only in 1927 that I. A. Reinwald produced the correct interpretation of their origin. As reported by E. L. Krynov (Priroda, 7, 55; 1960) these hollows represent meteorite craters. They were studied in great detail by Reinwald and after his death in 1945 by A. O. Aalos, who carried out a systematic excavation of these creters and collected a large amount of fragments and dust belonging to iron meteorites. The disposition of the seven craters of the Karlijarvi region suggests that, as in the case of the craters of Henbury in Australia, the Estonian craters are situated within an elliptical area of meteorite dispersion produced by a fall of meteorites which moved along a line stretching from south-south-west to north-north-east.

Reports of two meteorite falls in the U.S.S.R. have been forthcoming during the past year. According to M. A. Kashkai et al. (Priroda, 9, 109; 1960) an iron meteorite fell in Yardymly region, $\mathbf{S}$.W. of Baku, Azerbaijan, at 8.5 a.m. Novermber 24, 1959. This meteorite apparently broke into fragments before its fall as five distinct falls were registered. The collected fragments vary in weight from $360 \mathrm{gm}$. to $127 \mathrm{kgm}$. Calculations show that before fragmentation the meteorite was moving from the S.W. to the N.E. V. A. Yarmoluyk reports (Priroda, 11, $100 ; 1960)$ that a number of eyewitnesses observed a flight of a bolid accompanied by a flash and sound effect at $17 \mathrm{~h}$. $30 \mathrm{~m}$. local time on December 22, 1959 , near the settlement Nurki, Dzhudzhur Range, fringing the Okhotsk Sea coast. It is presumed that these effects were caused by a meteorite fall, but no fragmente of such have as yot been found in this region.

\section{Artificial Melting of the Arctic Ice}

A CONSIDERABLE handicap to navigation in the Arctic Ocean is presented by the delay of melting of ice in bays and river estuaries as compared with that in the open ocean. As described by I. S. Peschansky (Priroda, 7, 49; 1960), a most successful acceleration of the process of melting of ice has been achieved by dusting the surface of the ice with various dark-coloured materials along certain definite navigation lines. This allows a greater play of solar energy and the formation of 'radiation' channels a month and a half before the normal melting period of the ice.

\section{Flora of the Rugby District}

A GOOD example of the way an educational institution and the neighbouring community can work together is provided by a publication describing the flora of Rugby and its environs. It has been prepared by a former scholar, D. E. Allen, with records sup. plied by boys of the school and members of the town. To the original Flora, which was first published in 1957, has now been added a supplement providing details of recent discoveries (Rugby School Natural History Society. A First Supplement to The Flora of the Rugby District. Pp. 4. By D. E. Allen. (Rugby: George Over, Ltd.) 1s.).

\section{The Royal Irish Academy}

Aт a meeting of the Royal Irish Academy in Dublin on March 16, Prof. John L. Synge, director of the School of Theoretical Physics in the Dublin Institute for Advanced Studies, was elected president. Prof. J. Doyle, Prof. J. J. Tierney, Prof. B. Ó. Cuív and Prof. F. E. Hackett were re-elected as secretary, secretary for polite literature and antiquities, secretary for Irish studies, and treasurer respectively. On the retirement of Dr. A. Farrington, who had been assistant secretary since 1928, Mr. Liam de Paor was elected executive secretary. The following were elected honorary members: in the Section of Science, Sir Harold Jeffreys, Cambridge, Edgar Lederer, Gif-sur-Yvette, and Lamoraal Ulbo de Sitter, Leyden; in the Section of Polite Literature and Antiquities, Roman Jakobson, Harvard, and Jerzy Kuryłowicz, Cracow. Mr. J. C. Beckett, Dr. J. G. Belton, Dr. J. W. Harman, Mr. J. P. Haughton, Dr. N. A. Porter, Dr. Yasushi Takahashi and Mr. F. G. A. Winder were elected members of the Academy.

\section{The Royal Institution}

At the annual meeting of the Royal Institution, held on May 1, the following officers were elected for the year 1961-62: President, Lord Brabazon of Tara; Treasurer, Mr. W. E. Schall; Secretary, Brigadier H. E. Hopthrow; Managers, Mr. F. G. Brown, Sir Harold Roxbee Cox, Mr. E. R. Davies, Prof. Alexander Haddow, Mrs. H. K. Hawkes, Dr. R. Holroyd, Miss E. Henrietta Jebens, Mr. L. B. W. Jolley, Prof. L. A. Jordan, Sir Ben Lockspeiser, Dame Kathleen Lonsdale, Dr. H. Lowery, Mr. W. R. Stevens, WingCommander H. F. Tiarks and Prof. W. D. Wright; Visitors, Mr. A. D. Beynes-Cope, Mr. A. D. R. Caroe, Mr. Norman Clarke, Miss F. M. Eastwood, Mr. A. H. Ewen, Dr. D. H. Follett, Mr. G. J. Gollin, Mr. N. P. W. Moore, Dr. A. A. Moss, Mr. J. D. Peattie, Mr. Frank Poperwell, Mr. F. Y. Poynton, Dr. H. R. Rishworth, Miss D. Sidebottom and Mr. H. Stanesby.

\section{The Geological Society of London}

THE following were elected officers and council of the Geological Society of London at the annual general meeting held at Burlington House, Piccadilly, on April 26: President, Prof. S. E. Hollingworth, Yates Goldsmid professor of geology in the University of London; Vice-presidents, Prof. T. Neville George, professor of geology in the University of Glasgow; Dr. D. R. Grantham; Sir William Pugh, emeritus professor of geology in the University of Manchester, and lately director of H.M. Geological Survey; Dr. C. J. Stubblefield, director of H.M. Geological Survey; Secretaries, Mr. J. M. Edmonds, curator of Geological Collections, University Museum, Oxford; Dr. P. A. Sabine, principal geologist, H.M. Goological Survey. Foreign secretary, Prof. O. T. Jones, emeritus professor of geology in the University of Cambridge. Treasurer, Mr. P. Evans. Ordinary members of 